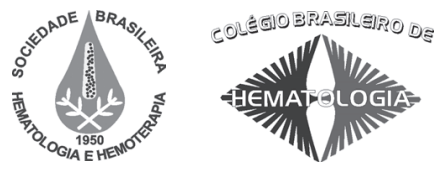

\title{
Correlation of IL-6 and IL-10 production following bone marrow transplantation with donor cytokine gene polymorphisms
}

\author{
Correlação da produção de IL-6 e IL-10 seguindo o transplante de medula óssea com os \\ polimorfismos de genes de citocinas do doador
}

Jeane E. L. Visentainer ${ }^{1}$

Sofia R. Lieber ${ }^{2,3}$

Ligia B. L. Persoli ${ }^{2,3}$

Silvia B. D. Marques $^{3}$

Afonso C. Vigorito ${ }^{3}$

Francisco J. P. Aranha ${ }^{3}$

Katia A. B. Eid ${ }^{3}$

Gislaine B. Oliveira ${ }^{3}$

Eliana C. M. Miranda

Cármino A. de Souza ${ }^{3}$
Several candidate gene studies have demonstrated that genetic polymorphisms in cytokine genes contribute to variations in the levels of cytokines produced and this variation may influence the occurrence and severity of complications after stem cell transplantation (HSCT). In this work we compared the serum concentrations of TNF- $\alpha, I F N-\gamma, I L-6$, $I L-10$, and TGF- $\beta 1$ in 13 recipients following HSCT with the $T N F^{-308}, I F N G^{+874}$, $I L 6^{-174}$, IL10 1082,-819,-592, and TGFB1 $1^{+869,+915}$ polymorphisms. Serum cytokine levels were assessed using commercial ELISA kits for TNF- $\alpha, I F N-\gamma, I L-6, I L-10$, and TGF- $\beta 1$ (BioSource ${ }^{\circledR}$, Nivelles, Belgium, Europe). Donor/recipient genotypes for these cytokine polymorphisms were analyzed by polymerase chain reaction-sequence-specific primer (PCR-SSP) with the Cytokine Genotyping Primers Kit (One Lambda, Canoga Park, CA, USA). We found correlation between the levels of IL-6 and IL-10 concentrations following HSCT and the IL6 $6^{-174}$ and IL10-1082,-819,-592 polymorphisms, but not for other cytokines investigated in this study. Those with genotypes associated with low production of IL-6 and IL-10 produced lower levels of these cytokines than those with genotypes associated with high or intermediate production of these cytokines $(P<0.05)$. Rev. Bras. Hematol. Hemoter. 2008;30(6):475-479.

Key words: Cytokine; polymorphism; GVHD; haematopoietic stem cell transplantation.

\section{Introduction}

Complex networks of cytokines dynamically interact homeostatically to regulate immune responses and other biological pathways. Variations in cytokine levels have been correlated with disease susceptibility and outcomes of transplantation. ${ }^{1-8}$

Investigating genetic host factors and immune responses may help to understand associations with complications after stem cell transplantation (HSCT), such as graft-versus-host disease (GVHD). Several candidate gene studies have demonstrated that genetic polymorphisms in cytokine genes contribute to variations in the levels of cytokines produced and this variation may influence the occurrence and severity of post-transplantation complications. ${ }^{9-21}$

In this work we compared the serum concentrations of TNF- $\alpha$, IFN- $\gamma$, IL-6, IL-10, and TGF- $\beta 1$ in 13 recipients following HSCT with the $T N F^{-308}, I F N G^{+874}$, $I L 6^{-174}, I L 10^{-1082,-819,-592}$, and $T G F B I^{+869,+915}$ polymorphisms.

\section{Patients and Method}

Patients

Thirteen consecutive patients, who had undergone allogeneic HLA-identical HSCT in our center from April to December 2000 and had serum samples available, were

${ }^{I}$ Clinical Analyses Department, Maringá State University, Paraná, Brazil.

${ }^{2}$ Mackenzie Presbyterian University, São Paulo, Brazil.

${ }^{3}$ Haematology and Haematotherapy Centre Campinas State University, Campinas, Brazil.

Correspondence: Jeane Eliete Laguila Visentainer

Universidade Estadual de Maringá - Departamento de Análises Clínicas

Av. Colombo, 5790

87020-900 - Maringá-PR - Brasil

Phone: (+55 44) 3261-4847; Fax: (+55 44) 3261-4931

Email: jelvisentainer@uem.br 
enrolled in this study after informed consent. Characteristics of the patients are listed in Table 1. Transplanted individuals were followed up during 15 weeks after transplantation. This study was performed after approval of the Research Ethics Committee of the University Hospital of Campinas State University.

Transplantation procedures

All of the patients were prepared for HSCT according to appropriate protocols for their underlying and other diseases, as described elsewhere. ${ }^{22}$ A summary of pretreatment preparative regimens and GVHD prophylaxis is shown in Table 1. Grading of acute and chronic GVHD was performed using the Glucksberg et al. ${ }^{23}$ and Atkinson et al. ${ }^{24}$ criteria, respectively.

\section{Cytokine gene polymorphism analysis}

Cytokine genotypes were determined blind to the clinical outcome of transplantation for the 13 recipients and their donors. DNA was extracted and purified from whole blood collected in 5\% EDTA using the Puregene DNA Isolation Kit (Gentra Systems, Minneapolis, MN, USA) according to the manufacturer's instructions. Donor/ recipient genotypes for the $T N F^{-308}$, $I F N G^{+874}, I L 6^{-174}, I L 10^{-1082,-819,-592}$, and TGFB $1^{+869,+915}$ polymorphisms were analyzed by polymerase chain reactionsequence-specific primer (PCR-SSP) with the Cytokine Genotyping Primers Kit (One Lambda, Canoga Park, CA, USA). All amplifications were performed according to the manufacturer's recommendations. The PCR products were then visualized by electrophoresis in $2 \%$ agarose gel. Individuals were grouped into the predicted low, high, or intermediate producer phenotypes for these cytokines according to their genotypes as defined previously. ${ }^{25-29}$

\section{Measurement of serum cytokines}

Serum cytokine levels were assessed using commercial Enzyme Linked-ImmunoSorbent Assay (ELISA) kits for TNF- $\alpha$, IFN- $\gamma$, IL-6, IL-10, and TGF- $\beta 1$ (BioSource ${ }^{\circledR}$, Nivelles, Belgium, Europe). Assays were carried out as previously described. ${ }^{6}$

\section{Statistical Analysis}

Mean cytokine levels were calculated at different time intervals: preconditioning, post conditioning and weekly after HSCT until 15 weeks, or death or relapse of the patient and expressed as means \pm SEM (standard error mean). The cytokine levels were compared with the donor and recipient polymorphisms for these cytokines, using a t-test for independent samples (2-tailed). Statistical analysis was conducted using SPSS software version 10.0 (SPSS Chicago, IL), using $\mathrm{P}<0.05$ as significant. 


\section{Results}

\section{Clinical outcome}

Acute GVHD was seen in five patients: Grade II was recorded in two patients, Grade III in one patient and Grade IV in two patients. Three patients developed chronic GVHD, one with limited GVHD and the other two with extensive GVHD (Table 1). All patients developed bacterial infection and 5 patients presented viral infection and/or the viral disease after transplantation.

Correlation of the cytokine level production following HSCT with the cytokine polymorphisms

We previously reported the cytokine levels among 13 patients who received their transplants from HLA-identical siblings for treatment of hematologic malignancies in our centre. ${ }^{6}$ Table 2 demonstrates the distribution of cytokine gene polymorphisms in recipients and donors of HSCT.

In this study, we compared the levels of cytokines with the receptor and donor cytokine genotypes. We found correlation between the levels of IL- 6 and IL-10 following HSCT and the $I L \sigma^{-174}$ and $I L 10^{-1082,-819,-592}$ polymorphisms, but not for the other cytokines investigated in this study (Figures 1 and 2). Those with genotypes associated with low production of IL- 6 and IL-10 produced lower levels of these cytokines than those with genotypes associated with high and/or intermediate production of these cytokines $(\mathrm{P}<0.05)$.

\section{Discussion and Conclusion}

It has been hypothesized that there is a correlation between polymorphisms in the TNF, IFNG, IL6,IL10, and $T G F B 1$ genes and the differential production of the respective

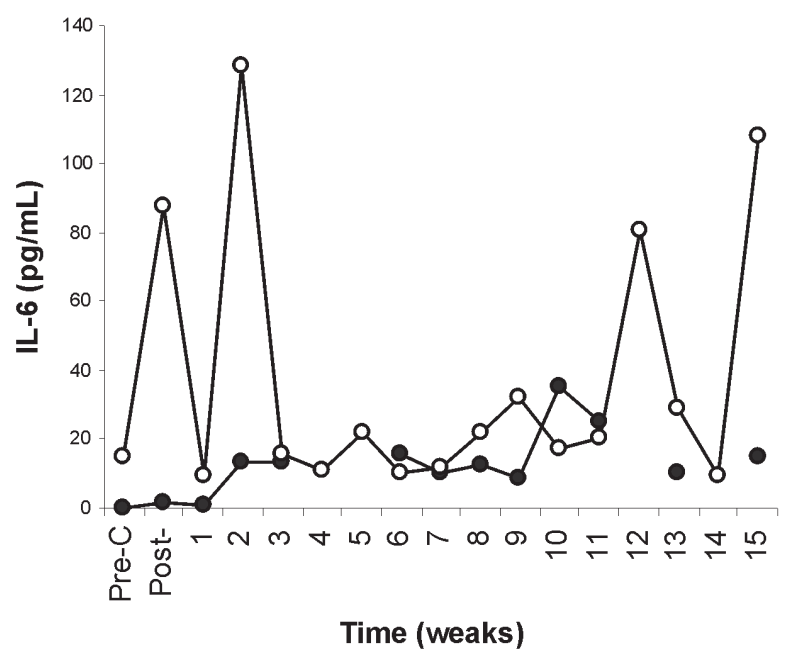

Figure 1. Kinetic profiles of serum IL-6 in patients with genotypes relative to low (closed circles) and high (open circles) production of this cytokine. Cytokine levels were expressed as mean \pm SEM. pre-C $=$ preconditioning week; post-C $=$ post-conditioning week .

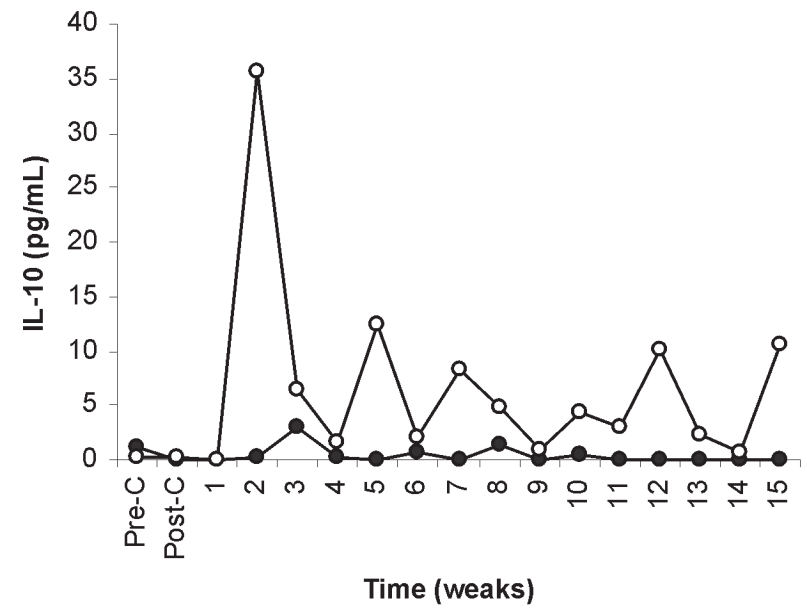

Figure 2. Kinetic profiles of serum IL-10 in patients with genotypes relative to low (closed circles) and high and/or intermediate (open circles) production of this cytokine. Cytokine levels were expressed as mean \pm SEM. pre-C $=$ preconditioning week; post $-\mathrm{C}=$ post conditioning week.

cytokines. It has also been shown that some of these polymorphisms affect transplant outcomes. ${ }^{9-21}$

In this study, we confirmed this correlation for IL-6 and IL-10 that are considered very important participants in the immune response in transplantation. Interleukin-6 is a pleiotropic cytokine with a central role in the host defense. Although it had been described as a pro-inflammatory cytokine, its anti-inflammatory and immunosupressor properties were recently reported. ${ }^{30}$ The role of IL-6 in the differentiation of T-helper lymphocytes has been discussed ${ }^{31}$ and a better understanding may clarify its participation in immunology mechanisms observed in the transplant outcome.

Interleukin-10 is an important immunoregulatory cytokine in humans produced by monocytes, macrophages, $\mathrm{B}$ cells, T cells and mast cells. ${ }^{32}$ It inhibits production of pro-inflammatory cytokines including TNF- $\alpha$, IL-1, IL-6 and IL- $8 .{ }^{33}$ Considering that these cytokines play an important role in the pathogenesis of GVHD ${ }^{8}$, IL-10 could be an essential regulator of immune response after transplantation.

Due to the special situation of stem cell transplantation, where many cytokines participate and interact, we would suggest the importance of a prospective study involving more patients and other cytokines in stem cell transplantation.

\section{Resumo}

Estudos de vários genes candidatos têm demonstrado que polimorfismos genéticos em genes de citocinas contribuem com variações nos níveis de citocinas produzidas e esta variação pode influenciar a ocorrência e gravidade de complicações após o transplante de células-tronco hematopoéticas (TCTH). Neste trabalho comparamos as concentrações séricas de TNF- $\alpha, I F N-\gamma, I L-6, I L-10$ e TGF- $\beta 1$ em 13 receptores seguindo o TCTH com os polimorfismos 
TNF ${ }^{-308}, I F N G^{+874}, I L 6^{-174}, I L 10^{-1082,-819,-592}$ e TGFB1 $1^{+869,+915}$. Os niveis séricos de citocinas foram medidos usando-se kits comerciais de ELISA para TNF- $\alpha$, IFN- $\gamma, I L-6, I L-10$ e TGF- $\beta 1$ (BioSource ${ }^{\circledR}$, Nivelles, Belgium, Europe). Os genótipos de doadores/receptores para estes polimorfismos de citocinas foram analisados pela reação em cadeia da polimerase com sequências especificas de primer (PCR-SSP) com o kit Cytokine Genotyping Primers (One Lambda, Canoga Park, CA, USA). Encontramos correlação entre os niveis de IL-6 e IL-10 seguindo o TCTH e os polimorfismos IL6 $6^{-174}$ e IL 10-1082,-819,-592, mas não para outras citocinas investigadas neste estudo. Aqueles com genótipos relativos à baixa produção de IL-6 e IL-10 produziram mais baixos niveis destas citocinas que aqueles com genótipos relativos à produção alta elou intermediária destas citocinas $(P<0,05)$. Rev. Bras. Hematol. Hemoter. 2008; 30(6):475-479.

Palavras-chave: Citocina; polimorfismo; GVHD; transplante de células-tronco hematopoéticas.

\section{Acknowledgment}

The authors wish to thank the HLA Laboratory in developing histocompatibility tests, the nurses for their skilful technical assistance in performing blood collections, and the donors and recipients that participated in this study.

\section{References}

1. Casanova JL, Abel L. Genetic dissection of immunity to mycobacteria: the human model: The Human Model. Annu Rev Immunol. 2002;20:581-620.

2. Stoycheva MV, Murdjeva MA. Cytokines in Salmonella infections. Folia Med (Plovdiv). 2004;46(4):5-10.

3. Lithgow D, Covington C. Chronic inflammation and breast pathology: a theoretical model. Biol Res Nurs. 2005;7(2):118-29.

4. Scheller J, Ohnesorge N, Rose-John S. Interleukin-6 trans-signalling in chronic inflammation and cancer. Scand J Immunol. 2006; 63(5):321-9.

5. Mok CC, Lau CS. Pathogenesis of systemic lupus erythematosus. J Clin Pathol. 2003;56(7):481-90.

6. Visentainer JE, Lieber SR, Persoli LB, Vigorito AC, Aranha FJ, de Brito Eid KA et al. Serum cytokine levels and acute graft-versushost disease after HLA-identical hematopoietic stem cell transplantation. Exp Hematol. 2003;31(11):1044-50.

7. Mathur A, Baz M, Staples ED, Bonnell M, Speckman JM, Hess PJ Jr et al. Cytokine profile after lung transplantation: correlation with allograft injury. Ann Thorac Surg. 2006; 81(5):1844-9.

8. Ferrara JL, Reddy P. Pathophysiology of graft-versus-host disease. Semin Hematol. 2006;43(1):3-10.

9. Turner D, Grant SC, Yonan N, Sheldon S, Dyer PA, Sinnott PJ et al. Cytokine gene polymorphism and heart transplant rejection. Transplantation. 1997;64(5):776-9.

10. Hahn AB, Kasten-Jolly JC, Constantino DM, Graffunder E, Singh TP, Shen GK et al. TNF-alpha, IL-6, IFN-gamma, and IL-10 gene expression polymorphisms and the IL-4 receptor alpha-chain variant Q576R: effects on renal allograft outcome. Transplantation $2001 ; 72(4): 660-5$.

11. Fernandes H, Koneru B, Fernandes N, Hameed M, Cohen MC, Raveche $\mathrm{E}$ et al. Investigation of promoter polymorphisms in the tumor necrosis factor-alpha and interleukin-10 genes in liver transplant patients. Transplantation. 2002;73(12):1886-91.

12. Dickinson AM, Cavet J, Cullup H, Wang XN, Sviland L, Middleton PG. GvHD risk assessment in hematopoietic stem cell transplantation: role of cytokine gene polymorphisms and an in vitro human skin explant model. Hum Immunol. 2001;62(11): 1266-76.

13. Middleton PG, Taylor PR, Jackson G, Proctor SJ, Dickinson AM. Cytokine gene polymorphisms associating with severe acute graftversus-host disease in HLA-identical sibling transplants. Blood. 1998;92(10):3943-8.

14. Cavet J, Middleton PG, Segall M, Noreen H, Davies SM, Dickinson AM. Recipient tumor necrosis factor-alpha and interleukin-10 gene polymorphisms associate with early mortality and acute graftversus-host disease severity in HLA-matched sibling bone marrow transplants. Blood. 1999;94(11):3941-6.

15. Takahashi H, Furukawa T, Hashimoto S, Suzuki N, Kuroha T, Yamazaki F et al. Contribution of TNF-alpha and IL-10 gene polymorphisms to graft-versus-host disease following allohematopoietic stem cell transplantation. Bone Marrow Transplant. 2000;26(12):1317-23.

16. Cavet J, Dickinson AM, Norden J, Taylor PR, Jackson GH, Middleton PG. Interferon-gamma and interleukin-6 gene polymorphisms associate with graft-versus-host disease in HLA-matched sibling bone marrow transplantation. Blood. 2001; 98 (5):1594-600.

17. Leffell MS, Vogelsang GB, Lucas DP, Delaney NL, Zachary AA. Association between TGF-beta expression and severe GVHD in allogeneic bone marrow transplantation. Transplant Proc. 2001; 33(1-2):485-6.

18. Tambur AR, Yaniv I, Stein J, Lapidot M, Shabtai E, Kfir B et al. Cytokine gene polymorphism in patients with graft-versus-host disease. Transplant Proc. 2001;33(1-2):502-3.

19. Socié G, Loiseau P, Tamouza R, Janin A, Busson M, Gluckman E, et al. Both genetic and clinical factors predict the development of graft-versus-host disease after allogeneic hematopoietic stem cell transplantation. Transplantation. 2001;72(4):699-706.

20. Dickinson AM, Cavet J, Cullup H, Wang XN, Sviland L, Middleton PG. GvHD risk assessment in hematopoietic stem cell transplantation: role of cytokine gene polymorphisms and an in vitro human skin explant model. Hum Immunol. 2001;62 (11):1266-76.

21. Laguila Visentainer JE, Lieber SR, Lopes Persoli LB, Dutra Marques SB, Vigorito AC, Penteado Aranha FJ et al. Relationship between cytokine gene polymorphisms and graft-versus-host disease after allogeneic stem cell transplantation in a Brazilian population. Cytokine. 2005;32(3-4):171-7.

22. Vigorito AC, Azevedo WM, Marques JF, Azevedo AM, Eid KA, Aranha FJ et al. A randomised, prospective comparison of allogeneic bone marrow and peripheral blood progenitor cell transplantation in the treatment of haematological malignancies. Bone Marrow Transplant. 1998;22(12):1145-51.

23. Glucksberg H, Storb R, Fefer A et al. Clinical manifestations of graft-versus-host disease in human recipients of marrow from HL-A-matched sibling donors. Transplantation. 1974;18(4):295304 .

24. Atkinson K, Horowitz MM, Gale RP, Lee MB, Rimm AA, Bortin MM. Consensus among bone marrow transplanters for diagnosis, grading and treatment of chronic graft-versus-host disease. Committee of the International Bone Marrow Transplant Registry. Bone Marrow Transplant. 1989;4(3):247-54.

25. Wilson AG, Symons JA, McDowell TL, McDevitt HO, Duff GW. Effects of a polymorphism in the human tumor necrosis factor alpha promoter on transcriptional activation. Proc Natl Acad Sci USA. 1997;94(7):3195-9. 
26. Turner DM, Williams DM, Sankaran D, Lazarus M, Sinnott PJ, Hutchinson IV. An investigation of polymorphism in the interleukin10 gene promoter. Eur J Immunogenet. 1997;24(1):1-8.

27. Awad MR, El-Gamel A, Hasleton P, Turner DM, Sinnott PJ, Hutchinson IV. Genotypic variation in the transforming growth factor-betal gene: association with transforming growth factorbeta1 production, fibrotic lung disease, and graft fibrosis after lung transplantation. Transplantation. 1998;66(8):1014-20.

28. Fishman D, Faulds G, Jeffery R, Mohamed-Ali V, Yudkin JS, Humphries $\mathrm{S}$ et al. The effect of novel polymorphisms in the interleukin-6 (IL-6) gene on IL-6 transcription and plasma IL-6 levels, and an association with systemic-onset juvenile chronic arthritis. J Clin Invest. 1998;102(7):1369-76.

29. Pravica V, Asderakis A, Perrey C, Hajeer A, Sinnott PJ, Hutchinson IV. In vitro production of IFN-gamma correlates with CA repeat polymorphism in the human IFN-gamma gene. Eur J Immunogenet. 1999;26(1):1-3.

30. Tilg H, Dinarello CA, Mier JW. IL-6 and APPs: anti-inflammatory and immunosuppressive mediators. Immunol Today. 1997;18(9): 428-32.

31. Diehl S, Rincón M. The two faces of IL-6 on Th1/Th2 differentiation. Mol Immunol. 2002;39(9):531-6.

32. Mosmann TR. Properties and functions of interleukin-10. Adv Immunol. 1994;56:1-26.

33. de Waal Malefyt R, Abrams J, Bennett B, Figdor CG, de Vries JE. Interleukin 10 (IL-10) inhibits cytokine synthesis by human monocytes: an autoregulatory role of IL-10 produced by monocytes. J Exp Med. 1991;174(5):1209-20.

Avaliação: Editor e dois revisores externos

Conflito de interesse: não declarado

Recebido: 25/06/2006

Aceito após modificações: 03/07/2007 